\title{
COMMENT
}

\section{Survival of the Common Law Abuse of Process Tort in the Face of a Noerr- Pennington Defense}

\author{
Joseph B. Maher †
}

The "abuse of process" tort, recognized by the common law of many states, ${ }^{1}$ aims to prevent plaintiffs from using litigation to pursue objectives other than those claimed in the suit. For example, the tort came into play when members of an Ohio yacht club attempted to use the court system to manipulate the behavior of other members. ${ }^{2}$ Within the Chagrin Lagoons Yacht Club, a dispute developed over the club leader's qualification for his position. This dispute led to the filing of multiple grievances with the club's grievance committee. These complaints, in turn, prompted disempowered members (who were also the subjects of several grievances) to file several lawsuits against the club. The plaintiffs, however, were not seeking to vindicate any claims officially filed with the Ohio state court. Rather, they were attempting to use the lawsuit as a weapon to coerce other members into dropping the existing club grievance against them. The plaintiffs went so far as to state this ulterior motive in a letter circulated to club members. The letter urged them to drop the grievances, stating, "Remember, no grievances, the case is dead and you members stop paying ... VOTE TO DROP THE

$\dagger$ B.S. 1995, Northwestern University; J.D. Candidate 1998, The University of Chicago.

1 See, for example, Robb $v$ Chagrin Lagoons Yacht Club, 75 Ohio St 3d 264, 662 NE2d 9, 14 (1996); Mozzochi v Beck, 204 Conn 490, 529 A2d 171, 173 (1987); Friedman v Dozorc, 412 Mich 1, 312 NW2d 585, 594 (1981).

2 The facts presented here are drawn from $R o b b, 662$ NE2d 9. The Ohio Supreme Court considered the facts in light of a motion for summary judgment. Id at 13. For illustrative purposes, this Comment assumes the truth of the stated facts. 
GRIEVANCES. ${ }^{33}$ Furthermore, one of the plaintiffs explained in a deposition that "the reasoning behind our litigation was, to keep membership from, in fact, rejecting our membership. ${ }^{n 4}$

Without any corrective law to stop this abuse, the plaintiffs could have successfully accomplished their ulterior goal by using such abusive litigation. ${ }^{5}$ Fortunately, however, Ohio common law, as with the common law in many states, provides a cause of action for "abuse of process." Ohio's formulation of this tort is typical and requires a plaintiff to satisfy three elements:

(1) that a legal proceeding has been set in motion in proper form and with probable cause; (2) that the proceeding has been perverted to attempt to accomplish an ulterior purpose for which it was not designed; and (3) that direct damage has resulted from the wrongful use of process. ${ }^{6}$

Importantly, the abuse of process tort emphasizes the plaintiff's subjective intent-not the objective merits of his claim. ${ }^{7}$

Today, the survival of the longstanding abuse of process tort appears threatened by the Noerr-Pennington doctrine, ${ }^{8}$ which im-

3 Id at 15.

4 Id.

- To the extent that the legal system is publicly financed with the goal of facilitating "genuine" legal actions, an abuse of process tort also protects taxpayers. See Steven Shavell, The Fundamental Divergence Between the Private and the Social Motive to Use the Legal System, $26 \mathrm{~J}$ Legal Stud 575, 577-78, 593 (1997) (arguing that the amount of litigation is socially excessive because litigants do not bear the full costs associated with their use of the court system).

- Robb, 662 NE2d at 14, quoting Yaklevich $v$ Kemp, Schaeffer \& Rowe Company LPA, 68 Ohio St 3d 294, 626 NE2d 115, 118 (1994). See also Fowler V. Harper, Fleming James, and Oscar S. Gray, The Law of Torts $\$ 4.9$ at 477, 478 (Little, Brown 2d ed 1986) ("The defendant may be liable although the immediate or apparent purpose of defendant's action was legitimate and the process properly issued."); Restatement (Second) of Torts $\$ 682$ comment b (1977) (The process must be used primarily to accomplish the ulterior end.). Some cases require an additional act in the use of the process that is "not proper" in the regular conduct of the proceeding. See Harper, James, and Gray, The Law of Torts § 4.9 at $482 \mathrm{n} 20$.

7 Compare the similar tort of "malicious prosecution" (sometimes more specifically referred to as "malicious civil litigation"), which operates to hold parties liable for instituting unfounded litigation. Typically, a plaintiff in a malicious prosecution action must show four elements: (1) a proceeding instituted by the defendant against the plaintiff, (2) termination of the proceeding in favor of the plaintiff, (3) absence of probable cause for the proceeding, and (4) malice. Harper, James, and Gray, Law of Torts $\S 4.8$ at 457-61. Because this tort requires that the underlying claim lack probable cause, malicious prosecution will be of no avail when the culpable plaintiff can find a claim supported by probable cause that will help her achieve her true, unrelated purpose. Another advantage of the abuse of process tort is that it may be alleged as a counterclaim within the same trial. The second malicious prosecution requirement, that a suit be favorably terminated, would otherwise require a defendant to initiate her own suit at a later time. This not only inconveniences the defendant, but also wastes judicial resources.

${ }^{8}$ The doctrine derives its name from two cases: Eastern Railroad Presidents Conference $v$ Noerr Motor Freight, Inc, 365 US 127 (1961), and United Mine Workers of America v Penning- 
munizes certain petitioning activity (including the bringing of a suit) from liability so long as the petitioning activity has an objective basis. ${ }^{9}$ Because the abuse of process tort imposes liability for the bringing of suit for ulterior purposes notwithstanding an objective basis for the suit, the Noer-Pennington doctrine and the abuse of process tort cannot coexist.

By virtue of the Supremacy Clause, ${ }^{10}$ the constitutionally rooted Noerr-Pennington doctrine must prevail over an inconsistent state law cause of action-or so some would argue. ${ }^{11}$ This Comment, taking a different view of the Noerr-Pennington doctrine, shows that in fact it is compatible with the abuse of process tort. It does this by demonstrating that the Noerr-Pennington doctrine stems from the Supreme Court's interpretation of certain federal statutes, rather than from the Petition Clause of the First Amendment to the Constitution. ${ }^{12}$ Because Noerr-Pennington stems from the Supreme Court's interpretation of certain federal statutes, the doctrine should be restricted to protect only petitioning conduct that might otherwise violate these statutes. With Noerr-Pennington thus restricted, the abuse of process tort can continue to protect defendants from legal actions instituted by plaintiffs for ulterior purposes. ${ }^{13}$

Part I of this Comment describes the Supreme Court case law developing the Noerr-Pennington doctrine, points out the vacillating

ton, 381 US 657 (1965).

- The Supreme Court's refusal to extend Noerr-Pennington protection to petitioning activity that lacks an objective basis is called the "sham" exception. See Professional Real Estate Investors, Inc $v$ Columbia Pictures Industries, Inc, 508 US 49, 51 (1993). See also Part I.C.

${ }^{10}$ US Const, Art VI, cl 2 ("This Constitution, and the Laws of the United States which shall be made in pursuance thereof... shall be the supreme Law of the Land.").

"See Ludwig $v$ Superior Court of Riverside County, 37 Cal App 4th 8, 43 Cal Rptr 2d 350, 360 n 17 (1995); Azzar v Primebank FSB, 198 Mich App 512, 499 NW2d 793, 796 (1993); Timothy P. Getzoff, Comment, Dazed and Confused in Colorado: The Relationship Among Malicious Prosecution, Abuse of Process, and the Noerr-Pennington Doctrine, $67 \mathrm{U}$ Colo L Rev 675, 677 (1996); Robert P. Faulkner, Petitioning: The Historical-Constitutional Argument in Favor of $a$ "Clear and Convincing" Standard, 28 USF L Rev 681, 690 (1994).

12 The outcome of the debate over whether the Noerr-Pennington doctrine finds its basis in statutory interpretation or in the First Amendment has constitutional implications for a number of state common law torts. If the First Amendment argument wins out, torts that hold parties liable for litigation conduct even when probable cause exists would necessarily be unconstitutional. For an example other than the abuse of process tort, consider tortious interference with contractual relations. If a third party induces one contracting party to bring suit against the other contracting party for breach of contract, states have allowed a tortious interference with contractual relations claim even though probable cause existed for instituting the breach of contract suit. See Proportion-Air, Inc v Buzmatics, Inc, 1995 US App LEXIS 25871, *6 (Fed Cir) (unpublished opinion) (" $[\mathrm{H}]$ ]ldings on the tortious interference [with business relationships], abuse of process and unfair competition counts depend upon rejection of the Noerr-Pennington defense . . . ."); Bond v Cedar Rapids Television Co, 518 NW2d 352, 356 (Iowa 1994) (applying Columbia Pictures, see Part I.C., to tortious interference with a contract).

${ }^{13}$ See notes $39-42$ and accompanying text. 
rationales underlying it, and discusses the "sham" exception, which denies immunity to any petitioning activity lacking an objective basis. Part II then surveys the use and characterization of the NoerrPennington doctrine in state courts and demonstrates how state courts have applied the doctrine outside its original context. Finally, Part III argues that although the Noerr-Pennington doctrine often is depicted as a constitutional doctrine, it actually finds its authority in the Supreme Court's interpretation of federal statutes. Therefore, outside of the context of petitioning activity that might violate those federal statutes, the Noerr-Pennington doctrine leaves the abuse of process tort intact.

\section{DEVELOPMENT OF THE NOERR-PENNINGTON DOCTRINE AND ITS SHAM EXCEPTION}

The Noerr-Pennington doctrine emerged from the Supreme Court's interpretation of the antitrust laws, providing protection for petitioning activity-the lobbying of legislators or the filing of lawsuits-in the antitrust context. ${ }^{14}$ In its initial incarnation, the doctrine prohibited plaintiffs from pointing to petitioning activity as the basis for a federal antitrust claim. Petitioning the various branches of government can often affect levels of competition. Specifically relevant to this Comment, petitioning to courts can be anticompetitive. For example, if company A successfully sues company B for patent infringement, the result will decrease competition. More importantly, even an inconclusive suit might decrease competition. After A files the suit, B may back down and refrain from the allegedly infringing conduct. Company B might then claim that company A's suit constitutes an antitrust violation. The Noerr-Pennington doctrine, however, would step in to protect company A from antitrust liability.

Still, the immunity is not all-encompassing. The Supreme Court recognized the need to prevent frivolous lawsuits designed merely to annoy defendants and to extract concessions from them. The Court therefore articulated a "sham exception" to Noerr-Pennington

\footnotetext{
${ }^{14}$ Sections 1 and 2 of the Sherman Act, one of the federal antitrust statutes, read in relevant part:

Every contract, combination in the form of trust or otherwise, or conspiracy, in restraint of trade or commerce among the several States, or with foreign nations, is declared to be illegal.

15 USC $\S 1$ (1994).

Every person who shall monopolize, or attempt to monopolize, or combine or conspire with any other person or persons, to monopolize any part of the trade or commerce among the several States, or with foreign nations, shall be deemed guilty of a felony ....
}

15 USC § 2 (1994). 
immunity. The sham exception removes from Noer-Pennington protection any petitioning activity without some objective merit. Importantly for the purposes of this Comment, however, if an objective basis exists, the petitioning party receives the immunity, regardless of any ulterior motive for engaging in the petitioning activity. This Part describes the historical development of the Noerr-Pennington doctrine and its sham exception.

\section{A. The Doctrine's Origin}

The Supreme Court first established the doctrine in Eastern Railroad Presidents Conference $v$ Noerr Motor Freight Inc ("Noerr"). ${ }^{15}$ In that case, the railroad industry had orchestrated a publicity campaign, intending to influence legislation that would impose more burdensome regulations on the trucking industry-one of its main competitors. ${ }^{16}$ The trucking industry complained that this publicity campaign was anticompetitive and therefore violated the Sherman Act. ${ }^{17}$

The Supreme Court held that the railroad industry did not violate the Sherman Act, thus establishing antitrust immunity for parties who seek anticompetitive ends by petitioning the government. ${ }^{18}$ While rigid enforcement of the trucking laws and passage of more restrictive trucking regulations would certainly impair the trucking industry's ability to compete with the railroad industry, the Court found no federal antitrust liability because the railroad industry pursued its objectives by (indirectly) petitioning the legislature. ${ }^{19}$ The Court concluded that " $[t]$ o [find a Sherman Act violation here] would impute to the Sherman Act a purpose to regulate, not busi-

1s 365 US 127 (1961).

${ }^{16}$ Id at 129-30. The railroad industry attempted to conceal its role in this campaign by creating the illusion that various third parties-rather than the railroaders themselves-were behind the publicity. Id. The deceptive nature of this technique, and its irrelevance in applying Noerr immunity, has important consequences in determining the scope of the doctrine. See note 114 and accompanying text.

${ }^{17}$ Id at 129.

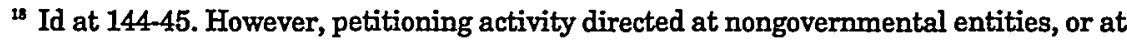
governmental entities not acting in a governmental capacity, does not receive NoerrPennington immunity. See Allied Tube \& Conduit Corp v Indian Head, Inc, 486 US 492, 509-10 (1988) (holding that petitioning of private, standard-setting association does not enjoy Noerr immunity); Fremaux $v$ Board of Commissioners of Hospital Service, 1997 US Dist LEXXIS 4098, *14 (E D La) (holding that a state hospital is not a government body that allows for NoerrPennington petitioning immunity); Stearns Airport Equipment Co v FMC Corp, 1996 US Dist LEXIS 21703, *10 (N D Tex) (Noerr-Pennington does not apply when petitioning is to the government acting in a proprietary capacity.). See also FTC v Superior Court Trial Lawyers Association, 493 US 411, 424-25 (1990) (holding that there is no Noerr-Pennington immunity for lawyers association using boycott "petitioning" tactics, which are themselves anticompetitive, in hopes of forcing legislative change).

${ }^{19}$ Noerr, 365 US at 143. 
ness activity, but political activity, a purpose which would have no basis whatever in the legislative history of that Act. ${ }^{200}$ As a second reason for interpreting the Act this way, the Court mentioned that construing the Sherman Act to find a violation in this situation might "raise important constitutional questions." planted the seeds for future controversy over whether the NoerrPennington doctrine ${ }^{22}$ finds its authority in the Sherman Act or in the Petition Clause of the First Amendment to the Constitution. ${ }^{23}$

\section{B. California Motor: Expansion to the Courts, Use of the Sham Exception, and a Shift in the Foundation}

The Supreme Court's decision in California Motor Transport Co $v$ Trucking Unlimited ${ }^{24}$ extended the Noerr-Pennington doctrine in two directions. First, the Court expanded the doctrine's scope from petitioning of legislatures to include petitioning of courts and administrative bodies. ${ }^{25}$ The Court reasoned that the same principles governing the petitioning of the executive and the legislature should apply to the petitioning of administrative agencies and courts. ${ }^{26} \mathrm{Sec}$ ond, the Court advanced a First Amendment rationale for granting Noerr-Pennington immunity, concluding that to hold parties liable for antitrust violations based on the petitioning of agencies and courts would impair petitioning rights. ${ }^{27}$ Thus, the Court's constitu-

${ }^{20}$ Id at 137. See also id at 141 ("The proscriptions of the Act, tailored as they are for the business world, are not at all appropriate for application in the political arena."). Compare David McGowan and Mark A. Lemley, Antitrust Immunity: State Action and Federalism, Petitioning and the First Amendment, 17 Harv J L \& Pub Pol 293, 297-98 (1994) (arguing that the Noerr Court was wrong in claiming that a meaningful difference exists between business and politics). The authors also argue that liability based on petitioning activity should be guided by substantive First Amendment law rather than antitrust doctrines. See id at 301.

${ }^{21}$ Noerr, 365 US at 137-38.

22 The second half of the doctrine's name comes from United Mine Workers of America $v$ Pennington, 381 US 657 (1965), decided several years after Noerr. This case extended the doctrine's immunity to petitioning intended to influence the executive branch. The Pennington Court affirmed the principle of Noerr by refusing to find Sherman Act liability when coal companies and a union petitioned the Secretary of Labor to establish a minimum wage "for employees of contractors selling coal to the TVA...." Id at 660. Smaller coal companies, who claimed that the larger coal companies conspired with the union to eliminate them from the market, could not use evidence of this petitioning activity to establish a Sherman Act violation. Id at 660,670. "Joint efforts to influence public officials do not violate the antitrust laws even though intended to eliminate competition." Id at 670.

${ }_{23}$ US Const, Amend I ("Congress shall make no law ... abridging ... the right of the people ... to petition the Government for a redress of grievances.").

${ }^{24} 404$ US 508 (1972).

${ }^{25}$ See id at 510-11.

20 The Court noted that the Noerr decision rested on a refusal to impute to the Sherman Act: (1) "a purpose to regulate, not business activity, but political activity, a purpose which would have no basis whatever in the legislative history of that Act," and (2) an intent to invade the right of petition. Id at 510, quoting Noerr, 365 US at 137-38.

${ }^{27}$ California Motor, 404 US at 510-12. See Part III.B-C, which argues that this First 
tional explanation of the Noerr-Pennington doctrine, an explanation alluded to only in dictum by the Noerr Court, ${ }^{28}$ provided an additional justification for Noerr-Pennington immunity beyond the Noerr Court's Sherman Act rationale.

The California Motor Court also applied an early version of the sham exception to Noerr-Pennington. Since the inception of the Noerr-Pennington doctrine, the Supreme Court has recognized that an exception to the immunity might exist when the petitioning is "ostensibly directed toward influencing governmental action, [but] is a mere sham to cover what is actually nothing more than an attempt to interfere directly with the business relationships of a competitor .... ."29 In California Motor, the Court found a "sham" where a group of in-state truckers conspired to institute state and federal proceedings to prevent out-of-state truckers from obtaining operating rights. ${ }^{30}$ Because the defendants were using the proceedings to bar their competitors "from meaningful access to adjudicatory tribunals," the Court held that the conduct fell within the sham exception, and thus the defendants could not avail themselves of NoerrPennington immunity. ${ }^{31}$ The Court failed, however, to define clearly what conduct falls outside of the sham exception-that is, what conduct does receive Noerr-Pennington immunity. For years, lower courts applied varying standards in identifying when the sham exception strips a party of immunity.$^{32}$ Finally, however, the Supreme Court stepped in to settle this confusion.

\section{Columbia Pictures' New Sham Test}

The Supreme Court most recently attempted to define the parameters of the sham exception in Professional Real Estate Investors, Inc $v$ Columbia Pictures Industries, Inc. ${ }^{33}$ The Court held that when an antitrust plaintiff alleges that the defendant's anticompetitive lawsuit constitutes a sham, a court must first inquire whether that suit was "objectively baseless. ${ }^{\text {m4 }}$ To satisfy this portion of the test, the party alleging a sham must show that "no reasonable litigant could realistically expect success on the merits. ${ }^{\text {n35 }}$ Only after finding

Amendment rationale no longer reflects current law.

${ }^{20}$ See text accompanying note 21 .

${ }^{20}$ Noerr, 365 US at 144. The sham test was first mentioned in dictum in Noerr, employed in California Motor, and refined in Professional Real Estate Investors, Inc $v$ Columbia Pictures Industries, Inc, 508 US 49 (1993). Columbia Pictures is discussed in Part I.C.

${ }^{30} 404$ US at 516.

31 Id at 511-12.

${ }^{32}$ See Columbia Pictures, 508 US at 55 n 3 (describing disagreement among courts).

508 US 49 (1993).

is Id at 60 .

${ }^{3}$ Id. 
this first element may courts look to the subjective intent of the defendant. ${ }^{36}$ Conversely, if the court finds that the suit does have some objective merit-if there was probable cause to institute the suit ${ }^{37}$ then the party who brought the initial lawsuit receives NoerrPennington immunity from liability under federal antitrust laws. ${ }^{38}$ An example helps clarify the interaction-and differing standards-of the abuse of process tort, Noerr-Pennington, and NoerrPennington's sham exception outside of the antitrust context. Suppose a manufacturing plant sits adjacent to land occupied by one of its suppliers. A contract dispute arises between the plant owner and his supplier over the price of supplies. Seizing on the fact that the

${ }^{36}$ To prove the suit was a sham, the court must then consider

whether the baseless lawsuit conceals "an attempt to interfere directly with the business relationships of a competitor," Noerr, supra, at 144 (emphasis added), through the "use [of] the governmental process - as opposed to the outcome of that process - as an anticompetitive weapon, [City of Columbia v Omni Outdoor Advertising, Inc,] 499 US [365,] 380 [(1991)] (emphasis in original)."

Columbia Pictures, 508 US at 60-61. After proving the previous litigation a sham (thus removing immunity), the plaintiff must then prove the elements of the antitrust violation. Id at 61.

${ }^{3}$ See id at 62. Justice Souter expressed concern that the majority's use of the phrase "probable cause" might cause courts to interpret the opinion as "transplanting every substantive nuance and procedural quirk of the common-law tort of wrongful civil proceedings [or malicious prosecution] into federal antitrust law." Id at 66-67 (Souter concurring). Thus, although the Court's sham test reads like the test for malicious prosecution, see note 7, it is not clear whether the previous litigation must be concluded (as it must for a malicious prosecution violation) before the plaintiff can bring an antitrust suit alleging that the defendant's conduct was a sham. Of course, termination of the previous suit in favor of the defendant in an action for malicious prosecution conclusively shows that probable cause existed. See id at $60 \mathrm{n} 5$.

Because the Columbia Pictures majority adopted the language of the malicious prosecution tort, see note 7, this tort will not have problems passing constitutional muster under a First Amendment Noerr-Pennington interpretation-except in jurisdictions that diverge from the standard elements. If, for example, a jurisdiction injects an element concerning the subjective intent of the defendant, the sham test could require the subordination of that element. See $I n$ re American Continental Corp, 102 F3d 1524, 1538 (9th Cir 1996), revd and remanded on other grounds as Lexecon, Inc v Milberg Weiss Bershad Hynes \& Lerach, 1998 US LEXIS 1598 (noting that, if applied, Columbia Pictures would alter Arizona's malicious prosecution tort); Hess $v$ Aetna Life Insurance Co, 1995 Ariz App LEXIS 12, *11-16 (unpublished opinion) (discussing alteration of Arizona's malicious prosecution tort under Columbia Pictures).

${ }^{38}$ Columbia Pictures, 508 US at 60 . The Ninth Circuit applied Columbia Pictures's narrow sham test in Liberty Lake Investments, Inc v Magnuson, 12 F3d 155 (9th Cir 1993). According to the facts of that case, a land developer ("developer $A$ ") rallied third parties to challenge, on environmental grounds, the development plan of a competitor ("developer B"). Id at 156, 158. Developer A went so far as to pay for the litigation costs incurred by the third parties. Id. Based on this conduct, developer B sued developer A for antitrust violations. Id at 156. The court, however, held that because the environmental suit was not objectively baseless, the sham exception did not apply and therefore the defendant should receive Noerr-Pennington immunity. See id at 159-60. It did not matter that developer A, who was developer B's business competitor, appeared indifferent to environmental concerns for their own sake. See id. Even though the mischievous competitor's only motivation may have been to drain the plaintiff's resources through instigation of the environmental challenges, the court refused to impose antitrust liability. See id at 158-59. 
manufacturing plant emits pollution, the supplier threatens to bring a nuisance suit unless the plant owner agrees to the supplier's version of the contract terms. ${ }^{39}$ The plant owner refuses, and the supplier sues.

The ensuing litigation involves four steps: (1) the supplier presses the nuisance claim; (2) the plant owner counterclaims with abuse of process, alleging that the real motivation for the nuisance claim is the contract dispute; (3) the supplier claims a NoerrPennington defense against the abuse of process counterclaim; and (4) the plant owner then argues that the underlying nuisance claim falls within the sham exception to the Noerr-Pennington doctrine. If Noerr-Pennington is a constitutional doctrine and thus overrides the abuse of process claim, then the factory owner alleging abuse of process will lose. ${ }^{40} \mathrm{He}$ will lose because the supplier had an objective basis for bringing the nuisance suit. If the Constitution, via the Noerr-Pennington doctrine, sets "objective baselessness" as the standard for imposing any liability, an abuse of process claim will almost always fail. ${ }^{41}$ On the other hand, if Noerr-Pennington is a federal

30 The contract dispute may involve issues about which reasonable parties disagree. The supplier might threaten and follow through with the nuisance suit if he thought that this course of action would bring a favorable settlement more cheaply than litigating the contract disagreement head on. For example, the contract dispute may present a close call to a trial court; this could make financial investment in litigation of this claim unattractive. However, if the supplier has a sure victory in hand on the nuisance claim, this may provide the leverage needed to convince the plant owner to fold on the contract claim.

to Requiring the abuse of process plaintiff to show that the previous litigation was objectively baseless-that the suit lacked probable cause-would negate one of the main uses of the tort. As in the hypothetical above, abuse of process is often alleged as a counterclaim. The ability to press abuse of process as a counterclaim allows the plant owner to reduce the costs imposed by the illegitimate (though not baseless) nuisance claim. Contrast abuse of process with the malicious prosecution tort. The malicious prosecution tort requires the plant owner to show that the nuisance suit lacks probable cause, a determination made upon the conclusion of that suit. See note 7.

${ }^{4}$ Grip-Pak, Inc $v$ Illinois Tool Works, Inc, 694 F2d 466 (7th Cir 1982), was a harbinger of this reality: "If all nonmalicious litigation were immunized from government regulation by the First Amendment, the tort of abuse of process would be unconstitutional-something that, so far as we know, no one believes." Id at 471. See also Gary Myers, Antitrust and First Amendment Implications of Professional Real Estate Investors, 51 Wash \& Lee L Rev 1199, 1246 (1994) (arguing that abuse of process tort is unconstitutional under the Petition Clause of First Amendment); Note, Limiting the Antitrust Immunity for Concerted Attempts to Influence Courts and Adjudicatory Agencies: Analogies to Malicious Prosecution and Abuse of Process, 86 Harv $L$ Rev 715 (1973) (attempting to influence the shape of the sham exception by drawing on these common law torts).

It is unlikely that in authoring the Columbia Pictures opinion, Justice Thomas, an ardent supporter of states' rights on federalism issues, intended to override common law concerning the abuse of process cause of action in almost every state. The validity of this interpretation is supported by the fact that the majority nowhere mentions the possibility of striking (or reshaping) this cause of action on constitutional grounds. Thus, the only other plausible explanation for eliminating the abuse of process tort based on Columbia Pictures is that this elimination results from an unintended consequence of the opinion. To support this explanation, the 
statutory doctrine and thus does not override the abuse of process tort in areas outside the federal statutory context, the factory owner will succeed in his abuse of process counterclaim. ${ }^{42}$

\section{STATE LAW APPROACHES TO THE APPLICATION OF NOERR-PENNINGTON}

The majority view among commentators is that NoerrPennington finds its origin in the Petition Clause of the First Amendment. ${ }^{43}$ To determine whether state courts have agreed with these arguments, this Part surveys state courts' treatment of the Noerr-Pennington doctrine when applying state tort law. Courts have varied greatly in their characterization and application of Noerr-Pennington, and four different approaches have emerged.

First, some state courts have embraced Noerr-Pennington as a doctrine based on the Petition Clause of the First Amendment and have applied it well outside the federal statutory context. ${ }^{44}$ For example, in Azzar $v$ Primebank FSB, ${ }^{45}$ shareholders of a bank claimed

Noerr-Pennington doctrine must be seen as merely another nickname for the First Amendment right to petition. See Part III.

42 This Comment assumes that the plant emits enough pollution to provide the basis for an objectively reasonable nuisance claim.

2 See, for example, Getzoff, Comment, $67 \mathrm{U}$ Colo L Rev at 677 (cited in note 11) (asserting that the doctrine is grounded in First Amendment, but limiting his focus to Colorado law without considering the broad implications for abuse of process under Columbia Pictures); Faulkner, 28 USF L Rev at 690 (cited in note 11) (Noerr-Pennington established a constitutional exception to the Sherman Act.); Daniel R. Fischel, Antitrust Liability for Attempts to Influence Government Action: The Basis and Limits of the Noerr-Pennington Doctrine, $45 \mathrm{U}$ Chi L Rev 80, 81, 94-104 (1977) (arguing that the boundaries of Noerr-Pennington immunity should be limited by First Amendment right to petition). But see Robert A. Zauzmer, Note, The Misapplication of the Noerr-Pennington Doctrine in Non-Antitrust Right to Petition Cases, 36 Stan $L \operatorname{Rev} 1243,1251-53$ (1984) (arguing that Noerr-Pennington is an antitrust doctrine).

4 See, for example, Pound Hill Corporation, Inc v Perl, 668 A2d 1260, 1263 (RI 1996) ("Although [Noerr-Pennington] arose in a context of application of the antitrust statutes, it is based upon the First Amendment right to petition the government for redress of grievances."); Ludwig $v$ Superior Court of Riverside County, 37 Cal App 4th 8, 43 Cal Rptr 2d 350, 360 \& n 17 (1995) (considering Noerr-Pennington a constitutional doctrine, and noting that "the principle applies to virtually any tort"); Bond $v$ Cedar Rapids Television Co, 518 NW2d 352, 354-56 (Iowa 1994) (noting that Noerr-Pennington is a First Amendment doctrine and applying it to a claim of tortious interference with contracts); Azzar v Primebank, FSB, 198 Mich App 512, 499 NW2d 793, 796 (1993) (stating that Noerr-Pennington is a constitutional doctrine that applies "regardless of the underlying cause of action").

t5 198 Mich App 512, 499 NW2d 793, 794-95 (1993). This decision is often quoted by courts extending Noerr-Pennington beyond the antitrust context, based on a First Amendment reading of the doctrine. See, for example, Computer Associates International, Inc $v$ American Fundware, Inc, 831 F Supp 1516, 1522 (D Colo 1993) (noting the "lack of reasoned authority" on the issue of extending Noerr-Pennington to state tort law claims, and then citing Azzar for support); Hi-Top Steel Corp v Lehrer, 24 Cal App 4th 570, 29 Cal Rptr 2d 646, 650 (1994) (quoting Azzar for support when applying Noerr-Pennington in a case involving causes of action for unfair competition and intentional interference with contractual relations and prospective economic advantage). 
that the bank and its board of directors breached their fiduciary duty by opposing the shareholders in an administrative proceeding. However, the court did not scrutinize the allegedly tortious conduct. Rather, the court granted immunity from all liability associated with a breach of fiduciary duty occurring in the course of the administrative proceedings. ${ }^{46}$ The Azzar court based this immunity on a constitutional understanding of the Noerr-Pennington doctrine. ${ }^{47}$ Thus, this Michigan appellate court extended Noerr-Pennington beyond federal antitrust law and into the realm of state common law. The court explained: "[T] he Noerr-Pennington doctrine is a principle of constitutional law that bars litigation arising from injuries received as a consequence of First Amendment petitioning activity, regardless of the underlying cause of action asserted by the plaintiffs. $\$ 48$

At the other end of the spectrum is the second application of Noerr-Pennington. Florida courts have restricted Noerr-Pennington to the realm of federal antitrust. ${ }^{49}$ In the events leading up to Florida Fern Growers Association, Inc $v$ Concerned Citizens, ${ }^{50}$ a citizen advocacy group objected to "each and every application for consumptive [water] use permits" by members of a fern growers association. ${ }^{51}$ The fern growers then filed suit, claiming that the advocacy group had tortiously interfered with their advantageous business relations. $^{52}$ The court rejected the advocacy group's plea for immunity from tort liability. ${ }^{53}$ Explaining that "Florida tort law 'already provides protection for the First Amendment right to petition the government," the court refused to apply the Noerr-Pennington doctrine. ${ }^{54}$ Thus, Noerr-Pennington does not apply to common law causes of action in Florida and consequently will not eviscerate Florida's abuse of process tort.

${ }^{46}$ Azzar, 499 NW2d at 796.

${ }^{47}$ Id.

${ }^{4}$ Id. This statement, however, is merely a tautology. Of course "First Amendment petitioning activity" is immune "regardless of the underlying cause of action asserted by the plaintifis." The difficulty comes in determining what qualifies as First Amendment petitioning. The question is: Does the petitioning conduct that Noerr-Pennington immunizes from antitrust liability always count as First Amendment petitioning activity? This is different from what the court's statement answers: Is First Amendment petitioning activity granted immunity?

4 See, for example, Florida Fern Growers Association, Inc v Concerned Citizens, 616 S2d 562, 566-68 (Fla App 1993). See also Londono v Turkey Creek, Inc, 609 S2d 14, 18 (Fla 1992) (declining to follow a federal district court's adoption of Noerr-Pennington's sham exception, Sierra Club v Butz, 349 F Supp 934, 938-39 (N D Cal 1972), in the context of state tort claims).

so 616 S2d 562, 564 (Fla App 1993).

si Id.

32 Id at 563.

${ }^{53}$ Id at 563-64.

ss Id at 566, quoting Londono, $609 \mathrm{~S} 2 \mathrm{~d}$ at 18. 
The third approach is simply to abstain from deciding whether Noer-Pennington is a constitutional doctrine. ${ }^{55}$ The D.C. Circuit, in Whelan $v$ Abell, ${ }^{56}$ recently took this approach in considering how Noerr-Pennington relates to the torts of both malicious prosecution and abuse of process. ${ }^{57}$ The district court, applying the Columbia Pictures sham test, granted summary judgment for the defendants on claims alleging these torts. ${ }^{58}$ The D.C. Circuit, however, noted that the "scope of these torts under District law is not altogether clear ${ }^{\prime 59}$ and refused to decide whether Noerr-Pennington applied: "We resolve the case without attempting to set forth any kind of encyclopedic position on the relation between the common law torts at issue here and the Noerr-Pennington doctrine-or between them and the First Amendment regardless of the idiosyncrasies of NoerrPennington."

Finally, one court incorporated the Noerr-Pennington doctrine into a state's common law. Applying Connecticut law, the Second Circuit considered how the Noerr-Pennington doctrine relates to a claim based on the Connecticut Unfair Trade Practices Act $\left({ }^{\text {"CUTPA") }}{ }^{61}\right.$ in Suburban Restoration Company Inc $v$ ACMAT

${ }^{s 5}$ See Whelan $v$ Abell, 48 F3d 1247 (DC Cir 1995) (discussed in text accompanying notes 56-60); Eastern Kentucky Resources v Arnett, 892 SW2d 617, 618-19 (Ky App 1995) (declining to determine whether Noerr-Pennington applies outside of the antitrust context); Kellar $v$ VonHoltum, 1997 Minn App LEXIS 958, *15-19 (refusing to decide whether Minnesota courts should adopt the Noerr-Pennington doctrine after noting that whether the doctrine bars abuse of process and malicious prosecution claims is a question of first impression in Minnesota); Snyder v American Association of Blood Banks, 144 NJ 269, 676 A2d 1036, 1050 (1996) ("We need not determine whether the Noerr-Pennington doctrine extends beyond antitrust law to tort liability."); Brock v Thompson, 1997 Okla LEXIS 120, *47 (resting the decision on state law because Noerr-Pennington's "status as a legal norm having constitutional dimension is in doubt"). See also In re American Continental Corp, 102 F3d 1524, 1538 n 15 (noting that the Ninth Circuit has not spoken definitively on "the question whether the Noerr-Pennington doctrine brings first amendment principles to bear on state law tort claims"); Bio-Technology General Corp $v$ Genentech, Inc, 886 F Supp 377, 382 n 3 (S D NY 1995) (noting that the Second Circuit has declined to rule on this issue).

${ }^{s 6} 48$ F3d 1247 (DC Cir 1995) (applying District of Columbia law).

${ }^{57}$ The court also reinstated a jury verdict in favor of the plaintiffs for tortious interference with prospective business advantage. See id at 1256-57. In so doing, the court decided that even if the First Amendment right to petition did conflict with this tort in some situations, neither Noerr-Pennington nor the First Amendment would grant immunity to the defendants when their petitions contained known falsehoods. See id at 1254-55. See also Part III.C (discussing the relevance of petitioning's legality to Noerr-Pennington's application).

${ }^{58}$ Whelan, 48 F3d at 1253.

${ }^{59}$ Id at 1257.

${ }^{60}$ Id at 1253-54.

${ }^{61}$ See Conn Gen Stat Ann $\S 42-110 b(a)$ (West 1992) ("No person shall engage in unfair methods of competition and unfair or deceptive acts or practices in the conduct of any trade or commerce."). The language of CUTPA is broader than the Sherman Act and the Connecticut legislature intended its interpretation to trace the interpretation of the Federal Trade Commission Act, 15 USC § 45(a)(1) (1994). See Conn Gen Stat Ann § 42-110b(b). 
Corp. ${ }^{62}$ The allegedly tortious conduct at issue was a suit by a losing state contract bidder to enjoin the state agency from awarding the contract to the low bidder. ${ }^{63}$ The low bidder argued that bringing this suit was an unfair trade practice under CUTPA ${ }^{64}$ After recognizing that if Noerr-Pennington is a constitutional doctrine, it would apply to Connecticut's statute and common law, ${ }^{65}$ the circuit court stated, "we are confident that Connecticut's courts would carve out a similar exception to CUTPA and the common law, whether or not they believed that they were required to do so by the United States Constitution."

Connecticut courts have not, however, fully considered the possible implications of extending the Noerr-Pennington doctrine into the domain of state tort law. For example, expansion of the NoerrPennington doctrine beyond the context of federal law is in tension with the Connecticut Supreme Court's most recent decision defining the elements of an abuse of process claim, Mozzochi $v$ Beck. ${ }^{67}$ In Mozzochi, the court, while reaffirming the existence of an abuse of process tort under the common law of Connecticut, discussed two concerns it had with the tort. First, the court expressed concern over the possible chilling effect on speech caused by the existence of an abuse of process claim. ${ }^{68}$ Second, it recognized the difficulty in discerning ulterior purposes from litigants' expressed goals in bringing suit. ${ }^{69}$ Wary of these difficulties posed by a purely subjective test, the Connecticut Supreme Court carefully fashioned a more explicit re-

c2 700 F2d 98 (2d Cir 1983).

Id at 99.

64 Id. The plaintiff also argued that the institution of the suit was a "tortious interference with a business expectancy under the common law ...." Id.

${ }^{\infty}$ Id at 101.

${ }^{6}$ Id at 102. Connecticut lower courts have recently echoed this reasoning. See Roncari Development Co v GMG Enterprises, 1997 Conn Super LEXIS 402, *10 (unpublished opinion) (reasoning that the "public policy of this State strongly supports the adoption of the NoerrPennington doctrine"); Gamlestaden PLC v Backstrom, 1995 Conn Super LEXIS 1585, *31-32 (unpublished opinion). See also Zeller $v$ Consolini, 1997 Conn Super LEXIS 1689, *8 (unpublished opinion) (refusing to resolve the issue of "whether the 'Noerr-Pennington Doctrine' applies to common claims of tortious interference and vexatious litigation").

" 204 Conn 490, 529 A2d 171 (1987). This case established the elements in the context of an abuse of process claim against attorneys. Expressing sensitivity to the responsibility "to assure unfettered access to our courts," id at 173, the court surely would not have set a higher standard for liability in situations involving persons other than advocates to the court. Thus, the context of the case takes nothing away from the point of the illustration. See TCW Realty Fund II $v$ Pearle Vision, Inc, 1996 Conn Super LEXIS 3240, *4-6 (unpublished opinion) (applying Mozzochi outside of the attorney context).

${ }^{6}$ See Mozzochi, 529 A2d at 173.

* See id at 174. As an example, the court described a situation where an abuse of process plaintiff characterizes the instigation of a medical malpractice suit as having the ulterior purpose of procuring a favorable settlement. See id. Courts have split on whether such a motivation constitutes an illegitimate ulterior purpose. See id (citing cases). 
quirement for the tort: the plaintiff must "point to specific misconduct intended to cause specific injury outside of the normal contemplation of private litigation. ${ }^{70}$

Mozzochi reveals that the Connecticut Supreme Court values the abuse of process tort enough to reshape it so as to minimize its possible negative effects. However, as shown above, ${ }^{71}$ imposing the Noerr-Pennington doctrine on this litigation-policing tort would erase the abuse of process tort from Connecticut's common law, because under that doctrine, regardless of any ulterior purpose, an objective basis for bringing suit would provide immunity from liability. Connecticut courts have not yet discussed this tension. ${ }^{72}$

In the end, whether the abuse of process tort will survive turns on whether courts characterize Noerr-Pennington as a constitutional or statutory doctrine. The next Part refutes the constitutional characterization and demonstrates the Noerr-Pennington doctrine's statutory grounding.

\section{NOERR-PENNINGTON'S INAPPLICABILITY AS A DEFENSE TO ABUSE OF PROCESS}

This Part contends that the Noerr-Pennington doctrine embodies no more than a common approach to the interpretation of certain federal statutes and that courts should not apply the doctrine outside the context of those statutes. The Supreme Court first recognized Noerr-Pennington immunity in the course of interpreting the Sherman Act. Although a subsequent Supreme Court decision may have temporarily altered this statutory interpretation grounding for the doctrine, the Court's most recent decisions indicate that the Noerr-Pennington doctrine cannot claim constitutional status.

${ }^{30}$ Id.

${ }^{71}$ See Part I.C.

72 The law of several other states share the same quiet tension. Compare, for example, Friedman $v$ Dozorc, 412 Mich 1, 312 NW2d 585, 594 (1981) (applying Michigan abuse of process law), with Azzar, 499 NW2d at 796 (applying Noerr-Pennington to Michigan tort claim), and Arim v General Motors Corp, 206 Mich App 178, 520 NW2d 695, 700-01 (1994) (same). In Pound Hill Corporation, Inc v Perl, 668 A2d 1260 (RI 1996), the Rhode Island Supreme Court explicitly recognized Noerr-Pennington as a constitutional doctrine, and applied the sham test to common law torts. Id at 1263 . The court claimed that Rhode Island's abuse of process tort would survive this reasoning, although Columbia Pictures would add a "constitutional gloss" to the tort. Id at 1263-64. However, as abuse of process in Rhode Island has the standard formulation, see Hillside Associates v Stravato, 642 A2d 664, 667 (RI 1994), it is difficult to see how the tort could survive. 
A. Creation of Noerr-Pennington Immunity as a Byproduct of Statutory Interpretation

Proponents of the First Amendment view raise two objections to asserting statutory authority as the basis for Noerr-Pennington immunity. First, the Noerr opinion itself raised the issue of First Amendment concerns. Second, the fact that the Supreme Court has applied the doctrine to other federal statutes indicates that NoerrPennington is not solely a construct of the Sherman Act; it must have some deeper authority.

Neither of these objections, however, is dispositive. While the Noerr opinion may have raised constitutional concerns, the Noerr Court expressly declined to rule that its holding was constitutionally inspired. Employing a familiar technique of statutory construction, the Court intentionally interpreted the statute to avoid the constitutional issue. Moreover, the Noerr Court explicitly relied on another antitrust immunity decision that was unquestionably a product of statutory interpretation. Taken together, these facts indicate that the Noerr Court's offhand reference to constitutional concerns does not indicate that Noerr-Pennington is a constitutional doctrine.

The second argument for a constitutional foundation-the fact that the Court has recognized petitioning immunity in contexts not involving the antitrust laws-is similarly unpersuasive. A close examination of the Court's "extension" of the doctrine indicates that the texts of other federal statutes independently support the incorporation of petitioning immunity.

\section{Noerr's explicit reliance on Sherman Act interpretation.}

The language in Noerr clearly indicates that the Court based its holding on an interpretation of the Sherman Act: "[W]e conclude that no attempt to interfere with business relationships in a manner proscribed by the Sherman Act is involved in this case. ${ }^{.73}$ The Court did mention possible constitutional problems that would arise from an alternative conclusion. The Court noted that holding the railroads liable under the antitrust law for their publicity campaign would lead to "a construction of the Sherman Act ... [that] would raise important constitutional questions. ${ }^{74}$ Thus, it would not "lightly impute to Congress an intent to invade these freedoms."

${ }^{73}$ Noerr, 365 US at 144 (emphasis added). The broad language of the Sherman Act facilitated the Court's aggressive reading of the Act to recognize petitioning immunity. The Court has said that "Congress ... did not intend the text of the Sherman Act to delineate the full meaning of the statute or its application in concrete situations." National Society of Professional Engineers $v$ United States, 435 US 679, 688 (1978).

${ }^{74}$ Noerr, 365 US at 137-38.

${ }^{73}$ Id at 138. 
Nevertheless, the Court expressly denied ruling on constitutional grounds:

The answer to the truckers' complaint also interposed a number of other defenses, including the contention that the activities complained of were constitutionally protected under the First Amendment .... Because of the view we take of the proper construction of the Sherman Act, we find it unnecessary to consider any of these other defenses. ${ }^{76}$

In interpreting the Sherman Act, the Noerr Court employed a common canon that avoids constitutional questions when faced with several possible interpretations of a statute. ${ }^{77}$ Using this canon of construction -often referred to as the Ashwander canon $^{78}$ - a court aggressively interprets a statute to avoid potential conflicts with the Constitution. ${ }^{79}$ The conflicts are only potential because the court declares that it is not interpreting the Constitution itself. In fact, the D.C. Circuit has cited Noerr in support of the proposition that "[a] court need not reach the constitutionality of a statute to acknowledge that the existence of significant constitutional questions counsel against imputing to Congress the intention to adopt the disputed meaning ... ${ }^{800}$ Hence, the D.C. Circuit seems to recognize that the Noerr Court, even though it mentioned constitutional concerns, was ultimately just interpreting the Sherman Act.

Because courts can extend the Noerr-Pennington doctrine simply by invoking the Ashwander canon in interpreting other statutes,

${ }^{76}$ Id at $132 \mathrm{n} 6$.

${ }^{77}$ In deciding not to hold the railroaders liable under the Sherman Act for their petitioning activity, the Court reasoned:

In the first place, such a holding would substantially impair the power of government to take actions through its legislature and executive that operate to restrain trade [the Parker concern, see Part III.A.2]. ... Secondly ... such a construction of the Sherman Act would raise important constitutional questions. ... For these reasons, we think it clear that the Sherman Act does not apply to the activities of the railroads ....

Id at 137-38 (emphasis added). Thus, the Court avoided the constitutional questions by choosing an alternative construction of the Sherman Act.

${ }^{73}$ This method of statutory interpretation is most often associated with Justice Brandeis's concurring opinion in Ashwander $v$ Tennessee Valley Authority, 297 US 288, 346-48 (1936). For a critical look at this principle of statutory interpretation, see Frederick Schauer, Ashwander Revisited, 1995 S Ct Rev 71.

${ }^{77}$ State courts, as well as federal courts, employ the Ashwander canon. See, for example, Russell v Board of County Commissioners, 1997 Okla LEXIS 80, *31; R.L. Augustine Construction Co $v$ Peoria Unified School Dist No 11, 188 Ariz 368, 936 P2d 554, 556 (1997); State v Berrocales, $141 \mathrm{NH} 262,681$ A2d 95, 96 (1996). This Comment does not argue against state courts using this statutory interpretation approach to grant Noerr-like immunity from various state statutes. This Comment only argues that courts should not read the Noerr-Pennington line of cases as a constitutional mandate.

${ }^{80}$ Boston and Maine Corp $v$ ICC, 911 F2d 743, 752 (DC Cir 1990), revd and remanded on different grounds, 503 US 407 (1992). 
the fact that courts read the Noerr-Pennington doctrine into these other federal statutes does not necessarily render Noerr-Pennington a constitutional doctrine. ${ }^{81}$ Thus, the expansion of Noerr-Pennington to other federal statutes does not mandate that the doctrine apply to the common law abuse of process tort.

\section{Noerr's reliance on Parker $v$ Brown.}

The fact that the Noerr Court viewed its holding as the logical extension of another type of statutorily based antitrust immunity further indicates that, despite the Noerr Court's reference to constitutional concerns, the Noerr-Pennington doctrine is statutorily grounded.

In Parker $v$ Brown, ${ }^{82}$ a decision rendered almost two decades before Noerr, the Supreme Court determined that the Sherman Act was inapplicable to states' implementing programs that have anticompetitive effects. ${ }^{83}$ The Parker Court held that a state program restricting the sale of raisins ${ }^{84}$ did not violate the Sherman Act, finding "nothing in the language of the Sherman Act or in its history which suggests that its purpose was to restrain a state ... from activities directed by its legislature. ${ }^{85}$ Respecting state sovereignty, the Court refused to read into the Sherman Act an "unexpressed purpose" to nullify state action of this sort. ${ }^{86}$

8s Deciding which federal statutes courts should construe to incorporate Noerr immunity is a separate inquiry beyond the scope of this Comment. Granting Noerr-Pennington immunity should follow only after considerations of the relevant statute's unique language and purposes. See, for example, David Franklin, Comment, Civil Rights vs. Civil Liberties? The Legality of State Court Lawsuits under the Fair Housing Act, 63 U Chi L Rev 1607, 1615-29 (1996) (discussing Noerr-Pennington in the context of the Fair Housing Act).

For examples of courts extending Noerr-Pennington to other federal statutes, see Eaton $v$ Newport Board of Education, 975 F2d 292, 298 (6th Cir 1992) (finding "support by analogy to the Noerr-Pennington doctrine" in immunizing petitioning activity from Section 1983 liability); Stern v United States Gypsum, Inc, 547 F2d 1329, 1344 (7th Cir 1977) (applying the Noerr "mode of analysis" to a Section 1985 claim). But see Warmus $v$ Hank, 1995 US App LEXIS $4208, * 27$ (6th $\mathrm{Cir}$ ) (unpublished opinion) (refusing to apply Noerr-Pennington to a Section 1983 claim based on abuse of legal process). Other courts applying Noerr-Pennington to other federal statutes, have reasoned that it should apply as a First Amendment doctrine. Boulware $v$ Nevada Department of Human Resources, 960 F2d 793, 800 (9th Cir 1992) (applying doctrine to Section 1983 claim); Video International Production, Inc $v$ Wamer-Amex Cable Communications, Inc, 858 F2d 1075, 1084 (5th Cir 1988) (same).

317 US 341 (1943).

${ }^{2}$ Id at 350-51. See also id at 352 ("Here the state command to the Commission and to the program committee of the California Prorate Act is not rendered unlawful by the Sherman Act since, in view of the latter's words and history, it must be taken to be a prohibition of individual and not state action.").

${ }^{8}$ Id at 344, 346-48 (When California growers experienced a surplus of raisins, state offcials established a marketing program to restrict competition and maintain the price of the commodity.).

${ }^{25}$ Id at $350-51$.

* Id at 351. The Court has since refined the Parker doctrine (although in ways irrelevant 
In Noerr, the Court noted that Parker immunizes from Sherman Act liability government action that creates a restraint on trade. The Court then declared that it was

equally clear that the Sherman Act does not prohibit two or more persons from associating together in an attempt to persuade the legislature or the executive to take particular action with respect to a law that would produce a restraint or a monopoly.... To hold that the government retains the power to act in this representative capacity and yet hold, at the same time, that the people cannot freely inform the government of their wishes would impute to the Sherman Act a purpose to regulate, not business activity, but political activity .... ${ }^{87}$

In other words, if, as Parker held, the Sherman Act allows states to enact legislation to restrain trade, it also must allow parties to petition for this legislation. To read the Sherman Act as prohibiting this activity would deny the government a "valuable source of information. ${ }^{n 88}$ Congress, the Court reasoned, could not have intended this result. ${ }^{89}$ Thus Noerr's holding was aimed at enhancing the efficacy of the immunity Parker provided..$^{90}$ To reach its conclusion, the Parker Court interpreted the Sherman Act. ${ }^{91}$ Thus, in order

to this Comment). See City of Columbia $v$ Omni Outdoor Advertising, Inc, 499 US 365, 370, 379 (1991) (holding that Parker does not apply directly to local government); Southern Motor Carriers Rate Conference, Inc $v$ United States, 471 US 48, 55-57 (1985) (holding that Parker immunity extends not just to states' regulation of commerce, but also to the private parties regulated by the state).

${ }^{87}$ Noerr, 365 US at $136-37$.

${ }^{88}$ Id at 139.

so Id.

${ }^{90}$ Not long after California Motor, Professor Daniel Fischel argued against interpreting Noerr as a natural extension of Parker. See Fischel, $45 \mathrm{U}$ Chi L Rev at 94-95 (cited in note 43). Whatever its logical strength, the argument is moot in light of Omni's recognition of the relationship between the two doctrines:

[B] leginning with [Noerr], we have developed a corollary to Parker: The federal antitrust laws also do not regulate the conduct of private individuals in seeking anticompetitive action from the government. [The Noerr-Pennington] doctrine, like Parker, rests ultimately upon a recognition that the antitrust laws, "tailored as they are for the business world, are not at all appropriate for application in the political arena."

Omni, 499 US at 379-80, quoting Noerr, 365 US at 141. See McGowan and Lemley, 17 Harv J L \& Pub Pol at 307 (cited in note 20) (describing Noerr as a "dramatic expansion" of the immunity provided in Parker because it protects unsuccessful petitioning). See also TEC Cogeneration, Inc $v$ Florida Power \& Light Co, 76 F3d 1560, 1570 (11th Cir 1996), modified on other grounds, 86 F3d 1028 (11th Cir 1996) ("Noerr/Pennington follows naturally from the [Parker] state action doctrine."); Huron Valley Hospital, Inc v City of Pontiac, 466 F Supp 1301, 1315 (E D Mich 1979) (discussing the interaction of Noerr-Pennington and Parker immunities).

${ }^{91}$ Parker, 317 US at 352 ("[I]n view of the [Sherman Act's] words and history, it must be taken to be a prohibition of individual and not state action."). In addition to finding that the raisin program did not violate the Sherman Act, the Court also upheld the validity of the program under the Agricultural Marketing Agreement Act of 1937, 7 USC $\S \S 601$ et seq (1988), 
to comport with Parker, the Noerr Court must also have engaged in statutory interpretation of the Sherman Act. ${ }^{92}$

\section{The independent statutory basis for the extension of petitioning immunity.}

Some critics of the statutory interpretation view assert that the Supreme Court's extension of Noerr-Pennington immunity to other federal statutes is evidence of the doctrine's constitutional character. ${ }^{93}$ These critics point to Bill Johnson's Restaurants, Inc $v \mathrm{Na}$ tional Labor Relations Board, ${ }^{94}$ a case involving petitioning activity in the labor relations context. A close examination of that opinion, however, reveals that the Court's holding again rested on statutory construction-not constitutional interpretation.

The Bill Johnson's Court employed a construction of the National Labor Relations Act ("NLRA") similar to the Noerr Court's Sherman Act construction. A restaurant had allegedly violated the NLRA by firing a waitress for attempting to organize a union. ${ }^{95}$ After the waitress, along with co-workers, picketed the restaurant and distributed flyers, the restaurant instituted a civil suit against the waitress and other demonstrators. ${ }^{96}$ The National Labor Relations Board ("NLRB") found that the restaurant instituted the suit for

and the Commerce Clause, US Const, Art I, § 8, cl 3. See Parker, 317 US at 348-49, 368.

$n$ Given Parker's interpretation of the Sherman Act, ironic consequences for state law (including the abuse of process tort) would flow from a First Amendment foundation for NoerrPennington and Columbia Pictures. The Parker Court based its interpretation largely on ideals of federalism and concern for state sovereignty. Parker, 317 US at 351; Omni, 499 US at 370, 372, 374 (noting that the Parker Court relied on principles of federalism and state sovereignty). By mandating application of the sham test to state litigation-policing torts, however, the Court would have implicitly replaced long-entrenched state law.

${ }^{*}$ See, for example, Milton Handler, Twenty-Five Years of Antitrust: Twenty-Fifth Annual Antitrust Review, 73 Colum L Rev 415, 434-35 (1973) (California Motor elevated "Noerr to the status of a constitutional principle."); Myers, 51 Wash \& Lee L Rev at 1239 (cited in note 41) (pointing to Columbia Pictures' citation to Bill Johnson's Restaurants, Inc $v$ National Labor Relations, 461 US 731 (1983), which applied a Noerr-type analysis to a claim under the National Labor Relations Act, as evidence of Noerr-Pennington's First Amendment foundation). Compare Hirschfeld $v$ Spanakos, 104 F3d 16, 19-20 (2d Cir 1997) (claiming, without citing cases, that Noerr-Pennington immunity has been extended beyond the antitrust context, and applying the Columbia Pictures test in the context of a Section 1983 claim brought based on a motion to stay a district court decision); Hamilton v Accu-Tek, 935 F Supp 1307, 1316-17 (E D NY 1996) (reasoning that Noerr-Pennington protects the First Amendment right to petition and has been extended to other federal statutes), citing Bill Johnson's, 461 US 731 (1983), with Snyder $v$ American Association of Blood Banks, 144 NJ 269, 676 A2d 1036, 1049 (1996) ("The United States Supreme Court has not extended the doctrine beyond the field of antitrust.").

* 461 US 731 (1983).

${ }^{5}$ Id at 733.

\% Id at 734. 
retaliatory purposes and issued an order requiring the restaurant owners to withdraw the state court complaint. ${ }^{97}$

The Supreme Court, however, held that the NLRB could not "halt the prosecution of a state-court lawsuit, regardless of the plaintiff's motive, unless the suit lacks a reasonable basis in fact or law." Construing the NLRA much as the Noerr Court had construed the Sherman Act, the Bill Johnson's Court noted the plaintiff's First Amendment interest in petitioning, but based its holding on its interpretation of the NLRA:

[T]he state plaintiff's First Amendment interest in petitioning the state court for redress of his grievance, his interest in having the factual dispute resolved by a jury, and the State's interest in protecting the health and welfare of its citizens, lead us to construe the Act as not permitting the Board to usurp the traditional fact-finding function of the state-court jury or judge. ${ }^{99}$

Thus, the Court's wariness over potential First Amendment conflicts was only one of several factors influencing the Court's interpretation of the NLRA. Finally, in determining whether the NLRB can stop a baseless suit, the Court "follow[ed] a similar course under the NLRA" to that taken in the Noerr line of cases and established a sham exception. ${ }^{100}$

Bill Johnson's illustrates how courts can apply NoerrPennington immunity to claims under various federal statutes without interpreting the Petition Clause. Significantly, the Court decided Bill Johnson's over ten years after California Motor-the case most strongly supporting the argument that the Noerr-Pennington doctrine is rooted in the First Amendment.

\section{B. California Motor: A Temporary Boost to the Status of the Noerr-Pennington Doctrine}

Although the Noerr-Pennington doctrine originally emerged from interpretation of the Sherman Act, the Supreme Court subsequently could have elevated its status by deciding that the First Amendment, in addition to the Sherman Act, requires this immunity. Proponents of the First Amendment argument find their strongest support in California Motor. Even though the case in-

${ }^{97}$ Id at 736-37.

${ }^{98}$ Id at 748.

${ }^{99}$ Id at 745 (emphasis added). See also id at 741 ("We should be sensitive to these First Amendment values in construing the NLRA ....").

${ }^{100}$ Id at 744. In Bill Johnson's, the sham exception applies to the vulnerability of suits normally immune from NLRB censorship. 
volved federal antitrust law-a context where Noerr-Pennington immunity had previously been explained on statutory interpretation grounds ${ }^{101}$ - the California Motor Court based its holding on First Amendment grounds:

We conclude that it would be destructive of [First Amendment] rights of association and of petition to hold that groups with common interests may not, without violating the antitrust laws, use the channels and procedures of state and federal agencies and courts to advocate their causes .... ${ }^{102}$

This language lends credence to the view that the Noerr-Pennington doctrine is an expression of First Amendment rights.

Commentators and courts have interpreted the constitutional dimension of California Motor in two ways. Most argue that California Motor either affirms that Noerr-Pennington is rooted in the First Amendment, or elevates it to constitutional status. ${ }^{103}$ In contrast, one commentator has suggested that California Motor's language "could be taken as nothing more than a restatement of the Court's fear in Noerr that if the antitrust laws were construed to reach political activity, they might infringe the right to petition." 104

There is, however, a third way to view California Motor: in the context of the entire Noerr-Pennington line of cases. Under this view, the Noerr-Pennington doctrine did gain First Amendment status for a short time. But after California Motor granted the Noerr-Pennington doctrine a constitutional pedigree, more recent Supreme Court cases have retreated from this position, returning Noerr-Pennington to its status as a doctrine based in statutory interpretation of certain federal statutes. ${ }^{105}$

\section{Deceit, Bribery, and Noerr-Pennington's Limited Protection}

In the 1991 case City of Columbia $v$ Omni Outdoor Advertising, Inc ("Omni"), ${ }^{106}$ the Supreme Court suggested that the Noerr-

${ }^{101}$ See Part IIII.A.

${ }^{102} 404$ US at 510-11.

${ }^{103}$ See, for example, Handler, 73 Colum L Rev at 434-35 (cited in note 93) (arguing that California Motor elevated "Noerr to the status of a constitutional principle."); Myers, 51 Wash \& Lee L Rev at 1208 (cited in note 41); Gary Minda, Interest Groups, Political Freedom, and Antitrust: A Modern Reassessment of the Noerr-Pennington Doctrine, 41 Hastings L J 905, 92729 (1990); Getzoff, Comment, $67 \mathrm{U}$ Colo L Rev at 686-87 (cited in note 11).

${ }^{10}$ Zauzmer, Note, 36 Stan $L$ Rev at 1252 (cited in note 43).

${ }^{100}$ But see Hartford Life Insurance Co $v$ Variable Annuity Life Insurance Co, Inc, $964 \mathrm{~F}$ Supp 624, 626 (D Conn 1997) (citing California Motor for the proposition that "[t]he [NoerrPennington] doctrine is derived from First Amendment principles guaranteeing the right to petition the government").

${ }^{106} 499$ US 365, 381-82 (1991) (holding that unlawful lobbying activity does not necessarily lose Noerr-Pennington immunity); id at 378-79 (noting that use of bribery as a petitioning 
Pennington doctrine grants antitrust immunity to bribery. This is significant because the First Amendment.Petition Clause certainly does not protect that form of "petitioning behavior." Although bribery is (in a pedantic sense) a type of petitioning, bribery is not considered conduct worthy of First Amendment protection. By its strong implication that the Noerr-Pennington doctrine provides more complete protection (from antitrust liability) than does the First Amendment, the Court indicated that the protections provided by the First Amendment are not coextensive with those provided by Noerr-Pennington. This indication supports the conclusion that Noerr-Pennington is not a constitutional doctrine, but a statutory one, and thus should be confined to its statutory context.

In Omni, the defendant Columbia Outdoor Advertising ( $\left.{ }^{\circ} \mathrm{COA}^{\prime)}\right)$ possessed 95 percent of the billboard advertising market share within Columbia, South Carolina. The plaintiff, Omni Outdoor Advertising, alleged that COA maintained this market position by conspiring with City Council members. In return for "advantages made possible by COA's monopoly, ${ }^{\text {108 }}$ the City Council passed an ordinance restricting the construction of new billboards. ${ }^{109}$ The Fourth Circuit had reinstated a jury verdict for the plaintiff on the Sherman Act violation, ${ }^{110}$ reasoning that the jury could have found that one of COA's purposes was to "deny [Omni] a meaningful access to the appropriate city administrative and legislative fora," thus constituting a sham. ${ }^{111}$ The Supreme Court rejected this theory, asserting that although this conduct "may render the manner of lobbying improper or even unlawful, [it] does not necessarily render it a 'sham."'112 The

method does not negate Parker immunity). See also Franklin A. Gevurtz, Politics, Corruption, and the Sherman Act after City of Columbia's Blighted View, 27 UC Davis L Rev 141, 168-83 (1993) (arguing that the Supreme Court was wrong to conclude that bribery should not form the basis for an antitrust violation).

${ }^{107}$ The First Amendment right to petition does not negate the constitutionality of the federal Bribery Act, 18 USC $\$ 201$ (1994), which criminalizes the act of giving or receiving anything of value in exchange for a specific favor performed by a public official. See also Whelan $v$ Abell, 48 F3d 1247, 1255 (DC Cir 1995) ("However broad the First Amendment right to petition may be, it cannot be stretched to cover petitions based on known falsehoods.").

${ }^{108}$ Omni, 499 US at 367, quoting Brief for Respondent 12, 16.

${ }^{109}$ Id at 368.

${ }^{110}$ Id at 370.

"' Omni Outdoor Advertising, Inc v Columbia Outdoor Advertising, Inc, 891 F2d 1127, 1139 (4th Cir 1989).

${ }^{112}$ Omni, 499 US at 381 (emphasis added). The Court distinguished this type of conduct from the sham in California Motor. In that case, the defendants invoked the process (granting trucking rights) merely for the delay and cost it imposed. In contrast, COA approached the City Council with the main intention of persuading them to pass the ordinance, not to impose some procedural burden on Omni. Although possibly illegal, this was not a "sham" in the Noerr sense. Id at 381-82. But see Hamilton v Accu-Tek, 935 F Supp 1307, 1317 (E D NY 1996) ("[C]ourts have declined to invoke the protection of Noerr-Pennington where the political activity involved illegal, corrupt or unethical means."). 
Court went on to conclude: "If the denial [of access] was wrongful there may be other remedies, but as for the Sherman Act, the Noerr exemption applies. ${ }^{1113}$

In other words, COA may have acted illegally in preventing the City Council from lending an ear to Omni's concerns, but that fact would not affect whether COA receives Noerr-Pennington immunity. ${ }^{114} \mathrm{COA}$ had given free advertising to the Mayor and other politicians during elections. ${ }^{115} \mathrm{~A}$ prosecutor might characterize this conduct as bribery, but to hold COA liable for federal antitrust violations would convert "antitrust law into regulation of the political process"-something "that [the Supreme Court] sought to avoid."116 In this context, the Noerr-Pennington doctrine grants immunity only from the antitrust laws. It is a construct of the Sherman Act. In contrast, First Amendment petitioning conduct receives immunity from all liability. However, because bribery is not considered First Amendment petitioning activity, the First Amendment does not protect it. As Omni reveals, the immunity granted by Noerr-Pennington does not parallel that granted by the First Amendment. ${ }^{117}$ Thus,

${ }^{113}$ Omni, 499 US at 382 . While Omni was a six to three decision, the lone dissenting opinion agreed with this portion of the majority's analysis. Id at 398 (Stevens dissenting). See also Milton Handler and Richard A. De Sevo, The Noerr Doctrine and its Sham Exception, 6 Cardozo L Rev 1, 47 (1984) (arguing that when antitrust plaintiffs have meaningful access to challenge "deliberate misrepresentations or other improprieties of the defendants," the conduct should not fall within the sham exception to Noerr-Pennington).

"In In Noerr itself, the campaign led by the railroaders involved deliberate deception of the public and public officials. The Court, however, found that, "reprehensible as it is, [that deception] can be of no consequence so far as the Sherman Act is concerned." Noerr, 365 US at 145. The deliberate deception may violate campaign laws or regulations, but this unethical conduct cannot provide evidence for violations of the Sherman Act. Compare In re Circuit Breaker Litigation, 1997 US Dist LEXIS 14232, *19 (C D Cal) ("Noerr-Pennington even precludes antitrust liability based on the use of false statements to persuade the government to act."), with Fox News Network, LLC $v$ Time Warner, Inc, 962 F Supp 339, 345-46 (E D NY 1997) (describing a "corruption exception" to the Noerr-Pennington doctrine). Because the Fox News Network court implicitly viewed Noerr-Pennington as a First Amendment doctrine, it is not surprising that the court created a "corruption exception" in addition to recognizing the sham exception.

${ }^{115}$ Omni Outdoor Advertising, 891 F2d at 1136.

${ }^{116} \mathrm{Omni}, 499$ US at 382. See also id at 383 ("And if the invalidating 'conspiracy' [between petitioner and legislator] is limited to one that involves some element of unlawfulness (beyond mere anticompetitive motivation), the invalidation would have nothing to do with the policies of the antitrust laws."). See also Cow Palace Ltd $v$ Associated Milk Producers, Inc, 390 F Supp 696, 701-02 (D Colo 1975) (holding that a finding of bribery and illegal campaign contributions does not necessarily remove Noerr-Pennington immunity). A footnote in Columbia Pictures, 508 US at 61 n 6 ("We need not decide here whether and, if so, to what extent Noerr permits the imposition of antitrust liability for a litigant's fraud or other misrepresentations."), casts a shadow over this logic, revealing the Court's characteristic vacillation over the intricacies of Noerr-Pennington. However, the footnote is unclear. Most likely, it ought to read, "We need not decide whether ... Noerr permits the imposition of antitrust liability for ends accomplished through a litigant's fraudulent conduct or misrepresentations."

${ }^{117}$ As previously mentioned, the First Amendment protection of petitioning is not boundless. Of course, a legislative act can provide for more protection for petitioning conduct. Iegis- 
even if California Motor did transform Noerr-Pennington into a constitutional doctrine, Omni returned the doctrine to its statutory roots. ${ }^{118}$

The Omni Court's remand of other state law claims provides additional support for the conclusion that Noerr-Pennington is a statutory doctrine. While the Omni Court dismissed the Sherman Act claims, it remanded a claim based on the South Carolina Unfair Trade Practices Act. ${ }^{119}$ Upon remand, the appellate court dismissed this claim because Omni failed to show satisfactorily that COA's conduct affected the public interest (a requirement of the South Carolina Unfair Trade Practices Act). ${ }^{120}$ Thus, neither court used the Noerr-Pennington doctrine to dispose of the state law claim, as is consistent with a statutory doctrine interpretation. ${ }^{121}$ In contrast, if Noerr-Pennington is a constitutional doctrine, the First Amendment doctrine would have governed this state statutory claim and protected the defendant's petitioning conduct from liability under both the Sherman Act and the state act. The courts' failure to use NoerrPennington to dispose of the state law claims further indicates that the Noerr-Pennington doctrine is a federal statutory doctrine.

\section{Troublesome Misapplication}

By applying Noerr-Pennington immunity beyond federal statutory law, courts can run roughshod over areas of traditional state governance. Failure to comprehend the dissimilar nature of the two immunities-Noerr-Pennington and the First Amendment right to petition-can lead to unseemly results. For example, the Ninth Cir-

latures, subject to obvious political constraints, have the authority to repeal bribery laws and pass new laws protecting a new "right to bribe." Likewise, they could pass an antitrust law that excepts certain activity (bribery, for example) from that law. This is, in effect, what the Court's interpretation of the Noerr-Pennington doctrine has done. But because the First Amendment does extend that far, that doctrine must be based on statutory authority.

${ }^{118}$ Others might argue that California Motor simply elevated the "judicial petitioning" portion of Noerr-Pennington to constitutional status. Because Omni concerned legislative petitioning-returning this (the legislative) portion of Noerr-Pennington to statutory interpretation status-it may have left Noerr-Pennington resting on different authority depending on which branch of the government one is petitioning. However, it is doubtful that the Supreme Court trifurcated the doctrine in this manner given that Columbia Pictures failed to ground its reasoning explicitly in the First Amendment. Furthermore, in rejecting a purely subjective definition of "sham," the Columbia Pictures Court-dealing with judicial petitioning-cited the reasoning in Omni. This approving citation indicates the retention of a shared statutory foundation for Noerr-Pennington in its application to any branch of government.

${ }^{119}$ See Omni, 499 US at 384.

${ }^{220}$ See Omni Outdoor Advertising, Inc v Columbia Outdoor Advertising, Inc, 974 F2d 502, 507 (4th Cir 1992).

${ }^{121}$ See also Nursing Registry, Inc $v$ Eastern North Carolina Regional Emergency Services Consortium, Inc, 959 F Supp 298, 305-06 (E D NC 1997) (declining to decide state law claims after Noerr-Pennington immunized defendants against federal claims). 
cuit recently confounded the characteristics of the two immunities. In Sunwest Associates $v$ Davis, ${ }^{122}$ the plaintiffs alleged that the defendants "knowingly presented false information" in violation of Arizona law ${ }^{123}$ during their proceedings before the Planning Commission and City Council. ${ }^{124}$ The plaintiff, Sunwest Associates, attempted to characterize this alleged violation as a predicate act for a state racketeering claim. ${ }^{125}$ The court, quoting from Noerr, reasoned as follows:

Sunwest also claims that defendants' petitioning should not receive protection because it involved knowingly false statements. It is clear, however, that Noerr-Pennington protects misrepresentations in the political process. "Attempts to influence public officials may occasionally result in deception of the public, manufacture of bogus sources of reference and distortion of public sources of information." $\$ 126$

Because the court was applying the Noerr-Pennington doctrine outside its federal statutory domain, this (slightly innaccurate) quotation from Noerr was taken out of context. Noerr does not force states to shield parties from all liability when they make illegally deceptive statements before their tribunals; it merely prevents liability based on violations of specific federal statutes. ${ }^{127}$ Nonetheless, the Ninth Circuit applied the Noerr-Pennington doctrine outside the federal context and provided immunity from liability based upon violations of Arizona lobbying law. This contorted application has the potential to override states' determinations of acceptable conduct before their tribunals. Similarly, interpreting the Noerr-Pennington doctrine to strike down the abuse of process tort would impair state courts' ability to police abusive litigation behavior and to compensate the victims of that behavior. ${ }^{128}$

1221996 US App LEXIS 27564, *2 (9th Cir) (unpublished opinion).

${ }^{123}$ Ariz Rev Stat Ann $\S 13-2311$ (A) (West 1996):

[T]n any manner related to the business conducted by any department or agency of this state or any political subdivision thereof, any person who, pursuant to a scheme or artifice to defraud or deceive, knowingly falsifies, conceals or covers up a material fact by any trick, scheme or device or makes or uses any false writing or document knowing such writing or document contains any false, fictitious or fraudulent statement or entry is guilty of a class 5 felony.

${ }^{12}$ Sunwest Associates, 1996 US App LEXIS 27564 at *2. The defendants had successfully obtained approval to rezone property for use as a medical office building. Id.

${ }^{125}$ Id.

${ }^{126} \mathrm{Id}$ at *5, quoting Noerr, 365 US at 140.

${ }^{127}$ See Part III.C.

${ }^{123}$ Recent cases in the Second Circuit further illustrate how sloppy application of the doctrine can lead to its illegitimate preemption of state tort law. In Hirschfeld $v$ Spanakos, 104 F3d 16 (2d Cir 1997), the Second Circuit failed to cite any precedent when it stated: "The 
Erasing the abuse of process tort from state law would force would-be abuse of process plaintiffs to rely instead on the tort of malicious prosecution ${ }^{129}$ as a remedy. This remedy, however, provides cold comfort to victims who must go through a costly and timeconsuming trial process in order to meet the "favorable termination" requirement. Furthermore, even the parties who trudge through an ultimately successful defense will find no recompense if the offending party can mask its true motivation with a claim having probable cause.

\section{CONCLUSION}

Contrary to popular opinion, the Noerr-Penningtion doctrine is not constitutionally based. Instead, it is the product of statutory interpretation and is properly limited to the federal statutory context. ${ }^{130}$ Courts, therefore, should not use it to dictate state tort law standards. The doctrine can provide a useful analogy when courts interpret statutes that could be used to impose liability for petitioning activity. ${ }^{131}$ However, courts should not employ the doctrine as constitutional authority to negate longstanding state tort law. Incorrectly reading the sham test's standard as a First Amendment requirement would negate the abuse of process tort and allow parties to opportunistically use litigation as leverage in hidden disputes.

doctrine originated in the antitrust area, but it has been extended to provide immunity from liability for bringing other suits." Id at 19. Shortly after the Second Circuit issued this opinion, a district court quoted the above sentence as authority for extending Noerr-Pennington to state tort claims. See Riddell Sports, Inc v Brooks, 1997 US Dist LEXIS 3621, *15 (S D NY).

${ }^{129}$ See note 7.

${ }^{130}$ See the caveats to this assertion in notes 79 and 81.

${ }^{131}$ Columbia Pictures, 508 US at 59 ("[B]y analogy to Noerr's sham exception, we held that ... [a] lawsuit may not be enjoined under the National Labor Relations Act as an unfair labor practice unless such litigation is baseless."'). 